\title{
Dinamika Psikologis Remaja di Panti Asuhan: Studi Fenomenologi
}

\author{
Maria Setiarini ${ }^{1}$, Kalis Stevanus ${ }^{2}$ \\ 1, 2Sekolah Tinggi Teologi Tawangmangu, Jawa Tengah \\ 1maria.setiarini@gmail.com, 2kalisstevanus91@gmail.com
}

\begin{abstract}
This paper is intended to describe the psychological dynamics of adolescents living in orphanages. How are the psychological dynamics of adolescents in living their adolescence without direct guidance and affection from their parents? This study uses a qualitative approach with phenomenological methods. From the results of this study, it was concluded that there were significant differences in the psychological dynamics of adolescents living in orphanages because they had to be entrusted by parents with adolescents living in an orphanage because of their own desires. Psychologically, adolescents who are forced to live in orphanages tend to close themselves off from their environment. Meanwhile, adolescents who live in homes because of their own desires, tend to be more open to their environment. In addition, the age factor when they enter the orphanage environment also affects their psychological dynamics. Those who enter the orphanage when they are children tend to be more adaptable. Conversely, those who enter when they are teenagers tend to have more difficulty adapting. Therefore, it is hoped that the management of the orphanage can understand the psychological dynamics of adolescents and their struggles, so that it can help them to live adolescence properly, even without the presence of their biological parents.
\end{abstract}

Keywords: adolescents; orphanage; phenomenology; psychological dynamics

\begin{abstract}
Abstrak
Tulisan ini dimaksudkan hendak menggambarkan dinamika psikologis remaja yang tinggal di panti asuhan. Bagaimana dinamika psikologis remaja dalam menjalani masa remajanya tanpa bimbingan dan kasih sayang langsung dari orang tua mereka? Penelitian ini menggunakan pendekatan kualitatif dengan metode fenomenologi. Dari hasil penelitian tersebut diperoleh simpulan terdapat perbedaan signifikan dinamika psikologis remaja yang tinggal di panti asuhan karena terpaksa dititipkan oleh orang tua dengan remaja yang tinggal di panti karena keinginan sendiri. Secara psikologis, remaja yang terpaksa tinggal di panti asuhan cenderung menutup diri dari lingkungannya. Sementara remaja yang tinggal di panti karena keinginan sendiri, cenderung lebih terbuka dengan lingkungannya. Selain itu, faktor usia saat mereka masuk ke lingkungan panti asuhan juga berpengaruh terhadap dinamika psikologis mereka. Mereka yang masuk ke panti asuhan saat usianya masih anak-anak cenderung lebih mudah beradaptasi. Sebaliknya, mereka yang masuk di saat sudah berusia remaja cenderung lebih sulit untuk beradaptasi. Sebab itu, diharapkan agar pihak pengelola panti asuhan dapat memahami dinamika psikologis remaja dan pergumulan mereka, sehingga dapat menolong mereka untuk menjalani masa remaja yang sewajarnya, meskipun tanpa kehadiran orang tua kandung mereka.
\end{abstract}

Kata kunci: dinamika psikologis; fenomenologi; panti asuhan; remaja

\section{PENDAHULUAN}

Masa remaja adalah masa yang indah. Mungkin bagi sebagian orang kalimat itu adalah kalimat yang bisa diaminkan dengan mudah. Masa di mana sebagian orang bisa merasakan kebebasan, keceriaan, pergaulan yang bebas dengan banyak teman-teman sebaya, 
punya waktu yang banyak untuk bereksplorasi tentang banyak hal, dan masih banyak hal-hal menarik dan menyenangkan yang bisa dilakukan dan dikenang selama masa remaja. Namun bagi sebagian yang lain, mungkin tidaklah demikian. Sebagian yang lain mungkin harus menjalani masa remajanya dengan banyak mengalami hal-hal yang berat dan tidak menyenangkan.

Masa remaja merupakan suatu masa krisis. Bagi sebagian yang lain, perkembangan masa remaja mereka agak lebih lancar. Tetapi secara umum masa remaja merupakan salah satu dari masa transisi paling sulit dalam hidup. ${ }^{1}$ Usia remaja sebagaimana disebutkan Marbun dan Stevanus, masa remaja dinamakan usia labil, yakni masa transisi dari anak-anak menuju dewasa. Tidak hanya kondisi tubuh mereka yang mengalami perubahan, namun kondisi psikologis mereka pun mengalami perubahan. Perubahan psikologis tersebut mempengaruhi tingkah lakunya dalam hubungannya dengan lingkungan sosialnya. ${ }^{2}$ Di masa transisi ini, kehadiran dan perhatian serta kasih sayang dari orang tua dan juga orang-orang di sekitarnya menjadi suatu hal yang tentunya sangat diperlukan oleh remaja.

Remaja memerlukan perhatian dan kasih sayang dari orang tuanya untuk mendampingi mereka pada masa transisi. Seperti yang diungkapkan Stevanus, setiap manusia tanpa kecuali secara hakiki membutuhkan orang lain, membutuhkan kasih sayang dan juga penerimaan oleh orang lain. Terutama adalah orang tua kandung. ${ }^{3}$ Lalu bagaimana dengan remaja yang harus tinggal di panti asuhan? Apakah kebutuhan mereka akan kasih sayang dan perhatian dari orang tua itu dapat terpenuhi? Apakah mereka mengalami kesulitan dalam menjalani masa remaja mereka? Apa saja pergumulan mereka sebagai remaja yang harus tumbuh dan berkembang tanpa pendampingan dari orang tua mereka? Bagaimana cara mereka dalam menghadapi setiap pergumulan itu? Pertanyaan-pertanyaan itu adalah beberapa dari sekian banyak pertanyaan yang mendorong penulis untuk mencari jawabannya. Ditambah lagi kesan panti asuhan yang secara umum kurang baik di masyarakat, dan fakta bahwa anak-anak yang tinggal di panti asuhan itu ada yang masih memiliki orang tua kandung. Bagaimana kondisi psikologis mereka yang terpaksa harus berpisah dengan orang tua dan tinggal di panti asuhan?

Itu sebabnya, tujuan penelitian ini adalah mendeskripsikan bagaimana dinamika psikologi remaja dalam menjalani masa remaja di panti asuhan Dorkas Porong.

\section{METODE}

Penelitian ini menggunakan pendekatan kualitatif dengan metode fenomenologi untuk mendapatkan gambaran secara menyeluruh terkait dinamika psikologis remaja yang tinggal di panti asuhan Dorkas Porong. Penulis memilih metode ini karena tujuan studi fenomenologi adalah menjelaskan fenomena dalam kemurniannya ${ }^{4}$, dalam hal ini ada-

\footnotetext{
${ }^{1}$ Norman Wright, Konseling Krisis, Membantu Orang Dalam Krisis Dan Stres, 6th ed. (Jakarta: gandum mas, 2009), 225.

${ }^{2}$ Kalis Stevanus dan Stefanus M. Marbun, "Pendidikan Seks Pada Remaja," Fidei: Jurnal Teologi Sistematika dan Praktika Vol.2, No.2 (2019): 325-343.

${ }^{3}$ Kalis Stevanus, "Memaknai Kisah Orang Samaria Yang Murah Hati Menurut Lukas 10:25-37 Sebagai Upaya Pencegahan Konflik," BIA': Jurnal Teologi dan Pendidikan Kristen Kontekstual, 3, no. 1 (2020): 2.

${ }^{4}$ Farid Hamid, "Pendekatan Fenomenologi Dalam Suatu Ranah Penelitian Kualitatif," Penelitian Fakultas Saintek UIN Sunan Kalijogo Yogjakarta (2013), 82.
} 
lah fenomena dinamika psikologis remaja yang tinggal di panti asuhan Dorkas Porong. Pengamatan dan penggalian data dinamika psikologis secara individu maupun berkelompok dilakukan dengan cara observasi dan wawancara mendalam secara langsung terhadap remaja yang tinggal di panti asuhan tersebut.

\section{HASIL DAN PEMBAHASAN}

\section{Latar Belakang Remaja saat Masuk di Panti Asuhan}

Data yang penulis dapatkan dari temuan observasi dan wawancara mendalam, dapat dikategorikan berdasarkan usia dan latar belakang remaja saat masuk ke panti asuhan, adalah sebagai berikut:

\section{Usia masih Anak-anak dan karena Terpaksa}

RS adalah salah satu penghuni Panti Asuhan Dorkas yang berasal dari Padang, Sumatra Barat, yang sudah tinggal di sana lebih kurang 8 tahun. Latar belakang RS adalah anak ke empat dari enam bersaudara, orang tuanya adalah petani dan sejak berumur 7 tahun sudah dititipkan di Panti Asuhan Dorkas, bersama satu orang adiknya. Alasan orang tuanya menitipkan RS di panti adalah karena tidak mampu membiayai dan juga tidak ada yang mengurusi anak-anak di rumah selama orang tua mereka bekerja. Sejak RS datang di panti pada usia 7 tahun sampai sekarang sudah berumur 15 tahun dan duduk di kelas I SMP, tidak sekalipun RS berkomunikasi dengan orang tuanya, sehingga RS tidak mengetahui keberadaan dan kabar orang tuanya sekarang.

Berdasarkan hasil wawancara penulis dengan RS, penulis melihat bahwa kondisi psikologis RS cukup baik bila dibandingkan dengan remaja yang diasuh oleh orang tua kandungnya. Usia RS yang masih sangat muda saat datang ke panti, membuat RS tidak terlalu banyak kenangan tentang orang tua dan lingkungan asalnya. Bahkan menurut pengakuan RS, dia sudah lupa dengan orang tuanya, sehingga lebih mudah bagi RS untuk menerima orang tua asuhnya di panti dan juga teman-teman yang sama-sama tinggal di panti.

Kenangan yang masih tersimpan tentang orang tuanya adalah bahwa dulu mereka bekerja sebagai petani, dan mereka menangis saat melepas RS dan juga adiknya ke panti asuhan. Dan setelah RS tinggal di panti, tidak ada lagi komunikasi dengan orang tuanya. Kasih sayang dan perhatian orang tua didapatkan RS dari orang tua asuhnya di panti, yang dipanggil dengan sebutan Opa dan Oma. Bagi RS, peran Opa dan Oma sangat penting dalam hidupnya. Dia merasakan bahwa Opa dan Oma selalu berusaha untuk memberi perhatian dan kasih sayang kepadanya, sehingga dia tidak lagi merasa kehilangan orang tua kandungnya. Opa dan Omalah orang tuanya sejak dia datang di panti sampai sekarang.

Ketika penulis menanyakan apa saja pergumulannya sebagai remaja yang tinggal di panti asuhan, RS menjawab tidak ada pergumulan yang berat yang dia rasakan. Pertengkaran-pertengkaran dengan sesama anak-anak yang tinggal di panti asuhan dipandang RS sebagai hal yang biasa. Pergaulannya dengan teman-teman di lingkungan sekolah pun tidak ada masalah menurutnya. Semua berjalan biasa saja dan tidak ada yang menjadi masalah baginya. RS sudah menerima keadaan dirinya sebagai seorang anak yang harus tinggal di panti asuhan karena orang tuanya tidak mampu membiayai hidup- 
nya. Dan ketika pada akhirnya dia harus kehilangan komunikasi dengan orang tuanya, RS menerima keadaan itu sebagai hal yang memang harus dia terima dan jalani.

Selama kurang lebih 8 tahun tinggal di Panti Asuhan Dorkas, RS merasakan halhal sebagai berikut: 1) merasa tercukupi semua kebutuhan pokoknya, sandang, pangan dan papan; 2) cukup kasih sayang dari orang tua asuhnya; 3) sudah menganggap orang tua asuhnya sebagai orang tua sendiri; 4) tidak kesulitan dalam beradaptasi; 5) tertutup terhadap masalah pribadi.

\section{Usia masih Anak-anak, karena Keinginan Sendiri}

W adalah salah satu remaja putri penghuni panti asuhan Dorkas yang berasal dari Kalimantan Barat, yang sudah tinggal di panti kurang lebih 4 tahun. Latar belakang W adalah anak ketiga dari empat bersaudara, dan kedua orang tuanya masih ada dan tinggal di Kalimantan Barat. Pada usia yang masih dibilang anak-anak, yaitu 11 tahun, dengan kondisi ekonomi orang tua yang kekurangan, dan dengan keinginan untuk hidup mandiri, W memberanikan diri untuk tinggal di panti asuhan yang jaraknya sangat jauh dari daerah asalnya.

Ketika penulis menanyakan pergumulan apa yang $\mathrm{W}$ hadapi sebagai remaja yang tinggal di panti, cukup mengagetkan bahwa $\mathrm{W}$ menjawab tidak ada pergumulan yang berarti yang dia alami selama tinggal di panti. Justru $\mathrm{W}$ mengaku senang dengan kehidupan panti yang banyak aturan dan serba terjadwal kegiatannya, sehingga hidupnya lebih teratur, punya jam doa yang teratur, dan ada orang tua asuh yang memperhatikan dan mencukupkan kebutuhannya. Selama kurang lebih 4 tahun tinggal di Panti Asuhan Dorkas, W merasakan hal-hal sebagai berikut: 1) merasa tercukupi kebutuhan pokoknya, sandang, pangan, dan papan; 2) cukup kasih sayang dari orang tua asuhnya; 3) merasa senang dengan kehidupan di panti yang teratur; 4) tidak mengalami kesulitan beradaptasi, 5) terbuka terhadap masalah pribadi.

\section{Usia sudah Remaja dan karena Keinginan Sendiri}

TG adalah penghuni Panti Asuhan Dorkas yang berasal dari Nias, Sumatra Utara, yang sudah tinggal di panti kurang lebih 3 tahun. Latar belakang TG adalah anak ke enam dari tujuh bersaudara dan ayahnya meninggal dunia saat TG berusia 12 tahun. Alasan TG tinggal di panti adalah untuk mendapatkan pengalaman merantau ke luar dari daerahnya, selain memang ibunya kesulitan biaya untuk menghidupi TG dan saudara-saudaranya. Setamat dari SMP di Nias, akhirnya TG tinggal di panti asuhan Dorkas dan melanjutkan sekolahnya di Porong.

Usia TG yang remaja saat meninggalkan kampung halamannya, yaitu 15 tahun, dan keinginannya untuk merantau membuat dia harus menghadapi persoalan-persoalan psikologis di awal kedatangannya di panti. Perundungan dari teman di panti menjadi sebuah pengalaman yang tidak menyenangkan bagi TG. Sifatnya yang pendiam membuat dia enggan untuk membalas perundungan dari teman-temannya. Tapi di balik diamnya, TG memendam kekecewaan dan kesedihan atas perlakuan teman-temannya. Sempat terpikir untuk pulang ke kampung halamannya karena TG merasa kesulitan dalam beradaptasi dengan lingkungan barunya di panti. Namun berkat masukan dari orang tua asuhnya, yang dipanggil dengan sebutan Opa dan Oma, dan juga dari kesadaran dirinya, TG memutuskan untuk tetap tinggal di panti. TG tidak mau pulang ke 
kampung halamannya sebelum dia berhasil. 'Malu dengan orang tua dan orang-orang di kampung kalau pulang sebelum berhasil," kata TG.

Ketika penulis menanyakan pergumulan yang dialami TG sebagai remaja yang tinggal di panti, TG menjawab bahwa satu hal yang paling menjadi pergumulannya adalah tentang masa depannya. Keinginannya untuk kuliah jelas terkendala biaya. TG bahkan tidak berani bercita-cita karena bingung dengan apa yang harus dia rencanakan untuk masa depannya. "Apa saja saya mau kerjakan asal ada jalannya," itu yang dijawab TG saat penulis bertanya apa cita-citanya. Selama kurang lebih 3 tahun tinggal di Panti Asuhan Dorkas, TG merasakan hal-hal sebagai berikut: 1) merasa tercukupi kebutuhan pokoknya; pangan, sandang dan papan; 2) sempat merasakan tekanan psikologis karena perundungan dari teman-temannya; 3) tidak butuh waktu lama untuk beradaptasi; 4) tercukupi kebutuhan kasih sayang sebagai anak dari orang tua asuhnya; 5) gelisah tentang masa depannya; 6) merasa dibangun semangatnya oleh orang tua asuhnya.

\section{Usia sudah Remaja, karena Terpaksa}

$\mathrm{G}$ adalah salah satu penghuni panti asuhan Dorkas yang berasal dari Kalimantan Barat, yang sudah tinggal di panti kurang lebih 3 tahun. Latar belakang $\mathrm{G}$ adalah anak sulung dari 3 bersaudara dan ibunya sudah meninggal dunia. Alasan $G$ tinggal di panti asuhan adalah karena dipaksa oleh ayahnya, sehubungan dengan adanya permasalahan keluarga yang membuat keluarga besar $\mathrm{G}$ mengalami konflik dan ayahnya tidak bisa merawat $\mathrm{G}$ dengan baik dan seharusnya.

Cerita awal mula G bisa sampai di panti asuhan Dorkas cukup dramatis. Ayahnya hanya menyampaikan bahwa $\mathrm{G}$ akan sekolah di luar pulau, tapi tidak memberitahu dengan jujur bahwa $\mathrm{G}$ akan tinggal di panti asuhan. Bahkan tiket pesawat ke Surabaya pun tidak diperlihatkan kepada G karena seharusnya Manado yang dijanjikan ayahnya sebagai tempat $\mathrm{G}$ melanjutkan sekolah. Setelah sampai di panti dan terpaksa harus tinggal di sana, $\mathrm{G}$ butuh waktu beberapa bulan untuk bisa beradaptasi.

Ketika penulis menanyakan pergumulan terberat yang dialami sebagai remaja yang tinggal di panti asuhan, $G$ menjawab bahwa yang terberat baginya adalah saat di mana dia harus menerima kenyataan bahwa ayahnya membohongi dia sehingga dia harus tinggal jauh dari keluarga dan harus tinggal di panti asuhan. Kebiasaan G berbicara kasar di kampung halamannya seringkali membuat konflik dengan teman-teman panti yang juga membawa budaya asal daerahnya masing-masing. Konflik ini sering dialami G sampai saat ini, bahkan sampai berhari-hari tidak saling menyapa sesama teman panti.

Selama kurang lebih 3 tahun tinggal di Panti Asuhan Dorkas, G merasakan hal-hal sebagai berikut: 1) merasa tercukupi kebutuhan pokoknya; pangan, sandang dan papan; 2) merasakan tekanan psikologis karena perundungan dari teman-temannya; 3) mengalami kesulitan beradaptasi; 4) tidak dekat dengan orang tua asuhnya; 5) gelisah tentang masa depannya; 6) sering konflik dengan orang-orang di sekitarnya; 7) tertutup terhadap masalah pribadi.

\section{Dinamika Psikologis Remaja secara Umum}

Kata remaja yang dalam bahasa Inggrisnya adalah adolescence berasal dari bahasa Latin adolescere yang berarti tumbuh atau menjadi dewasa. Masa remaja memang adalah suatu perjalanan dari masa anak-anak menuju masa dewasa yang disertai perubahan 
fisik, psikis dan sosial. Batasan usia remaja belum disepakati oleh para ahli, karena memang perkembangan manusia bersifat individual dan tidak bisa sama antara individu yang satu dengan yang lainnya. ${ }^{5}$ Berbicara mengenai remaja tentu tidak bisa lepas dari topik kenakalan remaja. Dari sudut pandang psikologis, kenakalan remaja merupakan wujud ketidakmampuan remaja menyesuaikan diri dengan lingkungan sosial dan perubahan zaman yang cepat, serta konflik-konflik yang tidak terselesaikan dengan baik pada masa anak-anak maupun pada masa remaja. ${ }^{6}$ Ketidakmampuan dalam menyesuaikan diri dengan lingkungannya ini seringkali menimbulkan rasa putus asa yang kemudian menjadi salah satu pemicu munculnya masalah-masalah psikologis pada remaja, bahkan bisa sampai membuat mereka melakuan tindakan kriminal. Permasalahan psikologis pada remaja yang seringkali muncul antara lain: sikap menentang, minder, antisosial, mudah marah, mudah tersinggung, menutup diri dan sulit beradaptasi.

Dalam sebuah studi kasus, permasalahan psikologis pada individu akan sangat berhubungan dengan kecemasan dan ketidakberdayaan. ${ }^{7}$ Dan bila ini terjadi pada diri remaja, kemungkinan besar mereka akan mengalami saat-saat yang sulit yang disebabkan oleh permasalahan emosional mereka. Kecemasan dan ketidakberdayaan mereka tidak tertangani dengan semestinya. Hal ini bisa dimaklumi sebab di masa peralihan dari anak-anak menjadi dewasa, remaja belum memiliki kemampuan yang cukup untuk mengelola emosi dan menyelesaikan permasalahan mereka dengan baik. Reaksi remaja seringkali emosional dan berlebihan saat menghadapi peristiwa di sekitarnya sehingga tidak jarang mereka melakukan hal yang ekstrim saat menanggapi sebuah kejadian.

Persoalan dalam keluarga, misalnya ketidakhadiran orang tua dalam masa pertumbuhan anak-anaknya ${ }^{8}$, dan kasus perceraian orang tua ${ }^{9}$, juga dapat menjadi penyebab persoalan-persoalan psikologis pada remaja. Sebuah studi kasus yang dilakukan oleh Ardian Praptomojati menemukan bahwa anak yang orang tuanya becerai akan mengalami persoalan psikologis dalam perkembangannya. Anak korban perceraian merasakan bahwa orang tuanya tidak bisa memberikan perhatian seperti yang diharapkan, sehingga ia berusaha untuk melakukan hal-hal yang dapat mendatangkan perhatian dari orangorang di sekitarnya, seperti mengganggu teman, memukul, berteriak-teriak, berkata-kata kotor, ramai di kelas, dan sebagainya. ${ }^{10}$ Namun sebuah studi lain juga menemukan bahwa remaja yang orang tuanya bercerai juga ada yang mampu mencapai psychological wellbeing yang tinggi dengan keadaan keluarga yang masih berkonflik. Hal itu disebabkan karena partisipan mampu memilah-milah masalah yang ada di rumah dan

\footnotetext{
${ }^{5}$ Lia Amalia, "Dampak Ketidakhadiran Ibu TKW Terhadap Perkembangan Psikologis Remaja," Kodifikasia 5, no. 1 (2011): 82.

${ }^{6}$ Orthorita Putri Maharani dan Budi Andayani, "Hubungan Antara Dukungan Sosial Ayah Dengan Penyesuaian Sosial Pada Remaja Laki-Laki,” Jurnal Psikologi UGM 30, no. 1 (2003): 25.

${ }^{7}$ Mahjarona Sabilla, Athi' intihail Fajriah, and Badrotuz Zakiyah, "STUDI KASUS: DINAMIKA PSIKOLOGIS REMAJA DALAM RUANG LINGKUP KELUARGA DISFUNGSIONAL” 2 (2018): 4.

${ }^{8}$ Kalis Stevanus, Menjadi Orangtua Bijak: Solusi Mendidik Dan Melindungi Anak Dari Pengaruh Pergaulan Buruk (Yogyakarta: Yayasan Pusataka Nusatama, 2016), 23.

${ }^{9}$ Kalis Stevanus, Inner Healing (Yogyakarta: Kanisius, 2016), 45.

${ }^{10}$ Ardian Praptomojati, "Dinamika Psikologis Remaja Korban Perceraian: Sebuah Studi Kasus Kenakalan Remaja,” Jurnal Ilmu Perilaku (2018),9.
} 
lingkungan luar rumah serta mampu berpikir dewasa dengan masalah yang ada. ${ }^{11}$ Dalam hal tersebut, kedewasaan berpikir dan bersikap dari seorang remaja sangat memengaruhi bagaimana responnya terhadap kejadian di sekitarnya.

Dari beberapa studi kasus dan kejadian yang terjadi di sekitar kita, bisa dilihat bahwa remaja mengalami banyak persoalan-persoalan psikologi yang disebabkan oleh berbagai hal, baik itu dari dalam keluarga maupun dari lingkungan sekitar. Pendampingan dari orang tua dan lingkungan sangat diperlukan supaya para remaja tidak keliru dalam berespon atau mengambil tindakan. Keluarga jelas harus menjadi lembaga pertama yang mendidik dan menjadi tempat anak-anak untuk belajar berespon dengan benar atas segala dinamika psikologi yang mereka alami. Dikemukakan Kalis Stevanus, bahwa keluarga adalah tempat yang paling baik untuk pendidikan. Tidak ada tempat pendidikan yang lain, baik yang didirikan oleh pemerintah atau gereja, yang dapat menggantikan keluarga. Pendidikan di sekolah maupun gereja hanya membantu atau menambah apa yang kurang yang dilakukan oleh orang tua, tetapi bukan untuk menggantikannya. Pendidikan di luar rumah hanyalah pelengkap pendidikan yang telah didasarkan keluarga. ${ }^{12}$ Jadi jelas bahwa keluarga sangat berperan penting dalam mendampingi remaja dalam mengatasi masalah-masalah psikologis mereka.

\section{Dinamika Psikologis Remaja di Panti Asuhan Dorkas Porong}

Kehidupan di panti asuhan tentu berbeda dengan kehidupan di rumah. Hal yang paling membedakan tentu saja ketidakhadiran orang tua kandung dari anak-anak yang dititipkan di panti asuhan tesebut. Figur orang tua kandung terpaksa digantikan oleh orang tua asuh, dan mau tidak mau, panti asuhan adalah tempat yang sangat dibutuhkan bagi anak-anak yang tidak memungkinkan untuk tinggal bersama orang tua mereka.

Untuk tumbuh dengan baik, anak berhak mendapatkan pendidikan, lingkungan yang sehat, fasilitas kesehatan yang terjangkau, dan bahkan kecukupan gizi. Namun, jika orang tuanya tidak sanggup untuk memenuhi hak-hak anak tersebut, anak dapat diasuh atau diangkat oleh orang lain sesuai dengan peraturan perundang-undangan. ${ }^{13}$ Panti Asuhan Dorkas yang terletak di Jl. Bhayangkari No.139, Porong, Sidoarjo, Jawa Timur adalah salah satu panti asuhan yang bisa menjadi jawaban atas kebutuhan anak-anak akan kehadiran orang tua yang mampu memenuhi hak-hak mereka. Mayoritas penghuni panti asuhan Dorkas adalah anak-anak yang berasal dari keluarga tidak mampu, yang tidak dapat melanjutkan sekolah karena keterbatasan ekonomi orang tuanya.

Penulis memilih beberapa remaja di panti asuhan Dorkas untuk diwawancara berkaitan dengan dinamika psikologis mereka selama tinggal di panti asuhan dan bagaimana respon mereka atas permasalahan yang menyangkut sisi emosional mereka sebagi anak panti. Partisipan berasal dari latar belakang keluarga yang sama, yaitu dari keluarga tidak mampu. Orang tua mereka masih ada, baik itu yang lengkap atau hanya satu. Dan dari hasil wawancara tersebut penulis menemukan bahwa dinamika psikologis remaja yang tinggal di panti asuhan sesungguhnya tidak jauh berbeda dengan remaja yang

\footnotetext{
${ }^{11}$ Kartika Ayu Primasti and Aryani Tri Wrastari, "Dinamika Psychological Wellbeing Pada Remaja Yang Mengalami Perceraian Orangtua Ditinjau Dari Family Conflict Yang Dialami,” Jurnal Psikologi Kepribadian dan Sosial , Vol. 02, no. 03 (2013): 120-127.

${ }^{12}$ Kalis Stevanus, Mendidik Anak (Yogyakarta: Lumela, 2018).

${ }^{13}$ Mohammad Teja, "Pelindungan Terhadap Anak Telantar Di Panti Asuhan," P3Di VI, no. 05 (2014): 9-12.
} 
tinggal bersama orang tua kandungnya. Hal-hal yang memancing reaksi emosional mereka kurang lebih sama, yaitu merasa tidak dihargai, merasa tidak diterima di lingkungan baru, merasa tidak dimengerti, dan kebingungan dalam memikirkan masa depan. Respon mereka dalam menanggapi persoalan juga kurang lebih sama. Respon khas dari remaja, yaitu spontan, tidak memikirkan dalam-dalam apa yang mereka katakan atau mereka lakukan, dan emosi yang cepat berubah. Yang membedakan adalah remajaremaja di panti asuhan tidak bisa sebebas remaja yang tinggal bersama keluarganya unuk mendapatkan kasih sayang dan perhatian dari orang tuanya sehubungan dengan permasalahan psikologis yang mereka hadapi. Mereka lebih banyak mengatasi sendiri permasalahan-permasalahan mereka yang berkenaan dengan psikologis mereka. Atau mereka akan mengabaikan permasalahan mereka, dan membiarkan itu berlarut-larut karena ketidakberdayaan mereka untuk mengatasinya.

Dari hasil wawancara mendalam tersebut, jelas tampak bahwa remaja yang tinggal di panti asuhan karena terpaksa, akan cenderung lebih sulit beradaptasi dengan lingkungan panti asuhan. Mereka minder karena berasal dari daerah dan latar belakang orang tua mereka yang tidak mampu. Rasa minder ini sangat tampak lewat bahasa tubuh mereka ketika penulis berbicara dengan mereka satu per satu. Mereka mengakui bahwa mereka butuh waktu yang cukup lama untuk bisa beradaptasi dengan teman-teman dan lingkungan di panti asuhan. Perbedaan budaya, perasaan minder, perasaan takut tidak diterima, menjadi penyebab mereka sulit beradaptasi dan akhirnya menjadi penghalang untuk mereka bisa akrab dengan sesama penghuni panti asuhan. Respon mereka seringkali keliru ketika ada sesuatu yang mereka rasa tidak sesuai dengan apa yang mereka harapkan. Nada bicara dan perkataan teman yang berasal dari daerah yang berbeda adalah hal yang seringkali menjadi pemicu pertengkaran atau kesalahpahaman. Perkataan dan nada bicara temannya dianggap kasar dan meremehkan mereka, yang pada akhirnya bisa membuat mereka tersinggung dan bertengkar. Salah satu partisipan bahkan mengaku bahwa saat wawancara dia masih bertengkar dan tidak saling menyapa dengan salah satu teman di panti asuhan dan itu sudah berlangsung selama berhari-hari.

Ketika penulis bertanya bagaimana cara mereka meyelesaikan masalah mereka itu, terutama masalah yang berkaitan dengan sisi emosional mereka, jawaban mereka senada. Mereka membiarkan masalah itu berlalu dengan sendirinya, mereka tidak peduli, mereka tidak berusaha menyelesaikannya secara terbuka. Dan saat penulis bertanya apakah mereka menceritakan kepada orang tua asuh yang mereka panggil dengan Opa dan Oma mengenai permasalahan mereka, mereka menjawab tidak. Mereka cenderung menutup diri dan tidak mau diusik. Mereka lebih memilih untuk membiarkan masalah emosi itu terjadi, meskipun mereka mengaku sempat stress dan pernah ingin kabur dari panti asuhan. Dalam tingkat tertentu sebenarnya stress memang justru diperlukan untuk kita bisa maju dan meningkat. Tetapi jikalau terus menerus menumpuk, maka akibatnya akan menjadi sangat serius. Stress itu ibarat balon karet yang pada salah satu sisinya ada bagian yang tipis. Jika balon itu ditiup, makin lama semakin besar maka pada akhirnya balon itu akan pecah, yang dimulai dari bagian yang paling tipis tadi. ${ }^{14}$ Dalam kondisi seperti yang dialami remaja partisipan di panti asuhan tadi, tentu beresiko bila kondisi

${ }^{14}$ Hadi Sahardjo, KONSELING KRISIS DAN TERAPI SINGKAT: PERTOLONGAN DI SAATSAAT SULIT, 2nd ed. (Bandung: Pionir Jaya, 2008). 
stress tersebut dibiarkan tanpa ada penyelesaian. Peran orang tua asuh dan lingkungan sekitarnya jelas sangat diperlukan untuk membantu remaja-remaja yang mengalami permasalahan emosional agar mereka tidak melakukan tindakan-tindakan yang keliru dan membahayakan dirinya dan juga orang lain.

Berbeda dengan remaja yang tinggal di panti asuhan karena terpaksa dan berusia sudah remaja saat dia masuk, ternyata remaja yang tinggal di panti asuhan sejak masih anak-anak, meskipun bukan keinginannya sendiri, cenderung lebih mudah melewati fase adaptasi di awal masuk ke panti hingga selanjutnya. Kenangannya akan orang tua kandung yang belum terlalu banyak membuat dia lebih mudah menerima orang tua asuhnya di panti asuhan. Kedekatan secara emosional dengan figur pengganti orang tua kandung juga jelas terlihat lewat wawancara dengan penulis. Ketika penulis menanyakan apa cita-citanya, dia menjawab ingin menjadi seorang TNI untuk membuat orang tua asuhnya bangga pada dirinya. Relasi remaja ini dengan figur pengganti orang tuanya cukup dekat secara emosional namun tumbuh tanpa kekurangan kasih sayang, meskipun orang tua kandungnya tidak pernah lagi menghubunginya sejak awal dia dititipkan di panti asuhan.

Dari contoh-contoh dinamika psikologis remaja di atas, memang ada perbedaan dinamika psikologis yang dipengaruhi oleh usia saat mereka masuk di panti asuhan. Namun ada sebuah kesamaan di antara mereka dalam hal sikap tertutupnya kepada orang lain. Remaja-remaja yang tinggal di panti asuhan dengan latar belakang terpaksa, baik itu yang berusia masih anak-anak ataupun sudah remaja saat masuk ke panti asuhan, cenderung menutup diri kepada orang lain bila berkaitan dengan masalah pribadi. Mereka lebih memilih untuk membiarkan masalah pribadinya atau meyelesaikannya sendiri dengan mencoba memotivasi diri lewat buku dan tokoh-tokoh yang mereka pandang berhasil dalam hidupnya.

Tingginya jumlah anak yang tinggal di panti asuhan Dorkas dengan status masih memiliki orang tua, baik itu yang masih lengkap atau hanya satu, menunjukkan bahwa alasan ekonomi keluarga adalah penyebab utama mereka menitipkan anak mereka. Dan panti asuhan pada akhirnya menjadi jalan dan tempat pengharapan bagi orang tua tidak mampu untuk menitipkan anak mereka supaya bisa hidup layak dan bisa bersekolah. Orang tua kandung mereka mungkin tidak memikirkan dampak dari tinggal di panti asuhan terhadap psikologis anak mereka. Yang mereka pikirkan adalah anak mereka bisa tercukupi kebutuhan makan, minum, pakaian dan sekolahnya. Meskipun sudah banyak panti asuhan yang memenuhi persyaratan sebagai tempat yang memberikan pelayanan pengasuhan, namun tetap saja tempat terbaik bagi anak untuk tumbuh dan berkembang adalah berada di dalam lingkungan keluarganya sendiri.

Berdasarkan wawancara mendalam terhadap partisipan, dinamika psikologis yang terjadi pada diri remaja di panti asuhan dapat dipengaruhi oleh dua faktor, yaitu faktor internal dan faktor eksternal. Faktor internal diantaranya adalah krisis identitas dan kontrol diri yang lemah. Remaja yang mengalami krisis identitas akan cenderung minder dan menutup diri dari lingkungannya, serta lebih memilih mengatasi sendiri permasalahan yang mereka alami. Mereka lebih rentan mengalami gejolak emosi yang diakibatkan ketidakmampuan mereka dalam mengatasi permasalahannya. Sedangkan remaja yang kontrol dirinya lemah cenderung tidak bisa berrespon dengan benar terhadap 
hal-hal yang terjadi di sekitarnya. Meskipun secara pengetahuan mereka sudah tahu apa yang sebaiknya dilakukan, namun mereka tidak mampu mengontrol diri mereka agar bisa melakukannya dengan benar. Contoh faktor eksternal yang memengaruhi dinamika psikologis remaja yang tinggal di panti asuhan adalah keluarga, teman dan komunitas tempat mereka tinggal.

Berbicara mengenai keluarga bagi remaja yang tinggal di panti asuhan berarti berbicara tentang keluarga kandung dan keluarga asuh. Latar belakang keluarga kandung tentu berpengaruh dalam perkembangan emosi mereka, karena pondasi nilai dan pola kehidupan mereka sudah dibentuk oleh keluarga kandungnya terlebih dulu. Pendidikan yang salah di keluarga kandung pasti akan berdampak dalam perkembangan emosional dan perilaku remaja yang akhirnya tinggal bersama dengan keluarga asuhnya di panti asuhan. Faktor eksternal berikutnya adalah teman dan komunitas tempat mereka tinggal. Faktor teman dan komunitas jelas membawa pengaruh dalam dinamika psikologis remaja di panti asuhan. Teman yang baik, komunitas yang baik, akan membawa pengaruh yang positif bagi mereka. Demikian pula sebaiknya. Oleh sebab itu penting bagi pengelola panti asuhan untuk mengupayakan secara terus menerus menciptakan lingkungan yang sehat baik secara jasmani maupun rohani di panti asuhan, supaya semua penghuni panti asuhan memiliki teman dan komunitas yang sehat, yang akan menolong mereka untuk menjalani dinamika psikologis sebagai remaja dengan sewajarnya.

\section{KESIMPULAN}

Setelah menelaah hasil penelitian secara seksama tentang dinamika psikologis remaja di panti asuhan Dorkas tersebut berdasarkan kategori usia saat mereka masuk ke panti asuhan dan latar belakang mereka bisa tinggal di panti asuhan maka ditarik simpulan bahwa anak yang berusia masih anak-anak saat masuk panti asuhan cenderung lebih cepat beradaptasi dan mempunyai relasi yang dekat dengan orang tua asuhnya secara emosional. Sedangkan anak yang masuk di panti asuhan saat usianya sudah menginjak remaja cenderung lebih sulit beradaptasi dan mempunyai relasi yang tidak dekat dengan orang tua asuhnya secara emosional. Selain itu, didapati fakta bahwa anak yang masuk ke panti baik ketika masih berusia anak-anak maupun yang sudah menginjak remaja memiliki kecenderungan yang sama, yaitu tidak terbuka mengenai masalah-masalah pribadinya. Mereka memilih untuk menyimpan sendiri permasalahan mereka, dan membawa pergumulan mereka di dalam doa. Adanya jam doa yang teratur di panti asuhan Dorkas dan didikan dari orang tua asuh yang mereka panggil dengan sebutan Opa dan Oma untuk selalu mengutamakan jam-jam doa dalam segala aktifitas, membuat mereka memiliki waktu yang banyak dan teratur dalam membawa setiap pergumulan mereka di dalam doa. Sehingga meskipun mereka seringkali mengalami saat yang berat dalam menjalani dinamika psikologis sebagai remaja, sampai saat ini mereka kuat dan tetap punya harapan untuk masa depan mereka. 


\section{REFERENSI}

Amalia, Lia. "Dampak Ketidakhadiran Ibu Tkw Terhadap Perkembangan Psikologis Remaja." Kodifikasia 5, no. 1 (2011).

Hamid, Farid. "Pendekatan Fenomenologi Dalam Suatu Ranah Penelitian Kualitatif." Penelitian Fakultas Saintek UIN Sunan Kalijogo Yogjakarta (2013).

kalis Stevanus. Menjadi Orangtua Bijak: Solusi Mendidik Dan Melindungi Anak Dari Pengaruh Pergaulan Buruk. Yogyakarta: Yayasan Pusataka Nusatama, 2016.

Kalis Stevanus. Inner Healing. Yogyakarta: Kanisius, 2016.

_. "Memaknai Kisah Orang Samaria Yang Murah Hati Menurut Lukas 10:25-37 Sebagai Upaya Pencegahan Konflik." BIA': Jurnal Teologi dan Pendidikan Kristen Kontekstual, 3, no. 1 (2020).

- Mendidik Anak. Yogyakarta: Lumela, 2018.

Kalis Stevanus dan Stefanus M. Marbun. "Pendidikan Seks Pada Remaja." Fidei: Jurnal Teologi Sistematika dan Praktika Vol.2, no. No.2 (2019).

Mada, Universitas Gadjah. "Hubungan Antara Dukungan Sosial Ayah Dengan Penyesuaian Sosial Pada Remaja Laki-Laki.” Jurnal Psikologi UGM 30, no. 1 (2003).

Praptomojati, Ardian. "Dinamika Psikologis Remaja Korban Perceraian: Sebuah Studi Kasus Kenakalan Remaja.” Jurnal Ilmu Perilaku (2018).

Primasti, Kartika Ayu, and Aryani Tri Wrastari. "Dinamika Psychological Wellbeing Pada Remaja Yang Mengalami Perceraian Orangtua Ditinjau Dari Family Conflict Yang Dialami." Jurnal Psikologi Kepribadian dan Sosial 02, no. 03 (2013).

Sabilla, Mahjarona, Athi'intihail Fajriah, and Badrotuz Zakiyah. "STUDI KASUS: DINAMIKA PSIKOLOGIS REMAJA DALAM RUANG LINGKUP KELUARGA DISFUNGSIONAL" 2 (2018).

Sahardjo, Hadi. KONSELING KRISIS DAN TERAPI SINGKAT: PERTOLONGAN DI SAAT-SAAT SULIT. 2nd ed. Bandung: Pionir Jaya, 2008.

Teja, Mohammad. "Pelindungan Terhadap Anak Telantar Di Panti Asuhan." P3Di VI, no. 05 (2014).

Wright, Norman. Konseling Krisis, Membantu Orang Dalam Krisis Dan Stres. 6th ed. Jakarta: gandum mas, 2009. 